Part of Journal of Research of the National Bureau of Standards, Volume 25, October 1940

\title{
MEASUREMENT OF ELECTRODE POTENTIALS AND POLARIZATION IN SOIL-CORROSION CELLS
}

\author{
By Robert B. Darnielle
}

\section{ABSTRACT}

Electrode potentials in soil-corrosion cells cannot be measured accurately by the direct method because of the high resistance of soils and because of the nature of the electrolyte and the electrodes. Measurements made with a mechanical interrupter are also in error because of depolarization during the period of interruption. The method described by Hickling was adapted to measurements of these cells. The method was found to be accurate to about 0.01 volt over the range of current, resistance, and rate of depolarization of soil-corrosion cells.

\section{CONTENTS}

I. Introduction $\ldots \ldots \ldots$

II. Problem of measuring electrode potentials in soil-corrosion cells...- 422

1. Description of cell

2. Measurement of single-electrode potentials

3. Measurement of potential difference between the anode and cathode

III. Measurement of potentials by the Hickling method...... 425

1. Description of the method

2 . Values of potential for different periods of interruption

IV. Measurement of potentials by means of alternating current with elimination of $I R$ drop _...

V. Measurement of potential difference between the anode and cathode_ 430

VI. Comparison of potential measurements by different methods _._..._ 431

VII. References

\section{INTRODUCTION}

Rates of corrosion of steel in søils have been shown to be indicated by the relation between current and electrode potentials in corrosion cells in which current flows without applied emf [1]. ${ }^{1}$ Recently it has been shown that the current required to polarize the electrodes of the corrosion cell to the same potential in the absence of $I R$ drop may be taken as a measure of the rate of corrosion of steel in soils [2]. This current is equal to the short-circuit current which would flow if the cell had no resistance, and corresponds to the current in a natural corrosion circuit in which the electrodes are very close together. The electrode potential corresponding to this current has been termed "the corrosion potential."

Apart from the value of the current-potential relations in measuring corrosion rates, these relations are useful as a means for investigating the mechanism of the corrosion reaction in soils. In particular, such curves have been employed in determining the electrode at which the

1 Figures in brackets indicate literature references at the end of this paper. 
corrosion rate is chiefly controlled under various soil conditions [2]. Although measurement of the potentials of polarized electrodes of a variety of materials can be made with accuracy in certain solutions, it will be shown that the usual methods are not applicable to measurements in soil-corrosion cells.

\section{PROBLEM OF MEASURING ELECTRODE POTENTIALS IN SOIL-CORROSION CELLS}

\section{DESCRIPTION OF CELL}

The cell used in this investigation has been described by the writer and his associates. However, a brief description is presented herewith [2]. The anode of the cell is a disk separated from the screen cathode by a layer of moist soil, the whole being contained within a Bakelite ring (fig. 1). As the screen is more accessible to air than the disk, to which direct access of air is prevented by a layer of paraffin, the screen assumes a more noble potential. As a result, current flows within the cell from the disk to the screen when the electrodes are connected externally. In order that the aeration of the electrodes shall be determined by the permeability of the soil to air, the screen is covered by a layer of soil of the same thickness and at the same moisture content as the soil which constitutes the electrolyte. In the present study, steel electrodes were used. Single-electrode potentials were measured with respect to a saturated calomel electrode in contact with the surface of the soil, as indicated in figure 1. The term "electrode potential," as used in this paper, refers to this type of measurement as made in the absence of $I R$ drop.

If the short-circuit current through the cell is increased by the application of an external voltage, the electrodes may be brought to the corrosion potential, the corresponding current being taken as the measure of corrosion, as previously stated. The current-potential relation for soil-corrosion cells is illustrated in figure 2 by the solid lines. With the most corrosive soils in which the open-circuit voltage is 0.3 to 0.4 volt and the current required to bring the electrodes to the same potential is between 3 and $4 \mathrm{ma}$, it is unnecessary to extend the current-potential curves beyond the point of intersection in order to decide whether the corrosion rate is determined by the rate of the anode or the cathode reaction. With the less corrosive soils the curves are extended until the potential difference between the anode and cathode is about 0.4 volt. Potential differences between the anode and cathode to the left of the equipotential point are considered negative; those to the right of this point are positive.

\section{MEASUREMENT OF SINGLE-ELECTRODE POTENTIALS}

The potentials of polarized electrodes are commonly measured by the direct method, the potentials of the anode and cathode being measured with respect to a reference electrode while the polarizing current is flowing. As a potential measured under these conditions will include any potential difierence required to overcome resistance, errors from this source are made as small as possible by placing the tip of the reference electrode in close contact with the electrode whose potential is being measured, or by placing the reference electrode out of the path of current flow. According to Hickling [3], the error 
resulting from inclusion of some $I R$ drop in the measured potential is seldom avoided, as there always is present a certain surface resistance which may be due to gas evolution, depletion of electrolyte in the layer in contact with the electrode, or, in the case of an anode, to a poorly

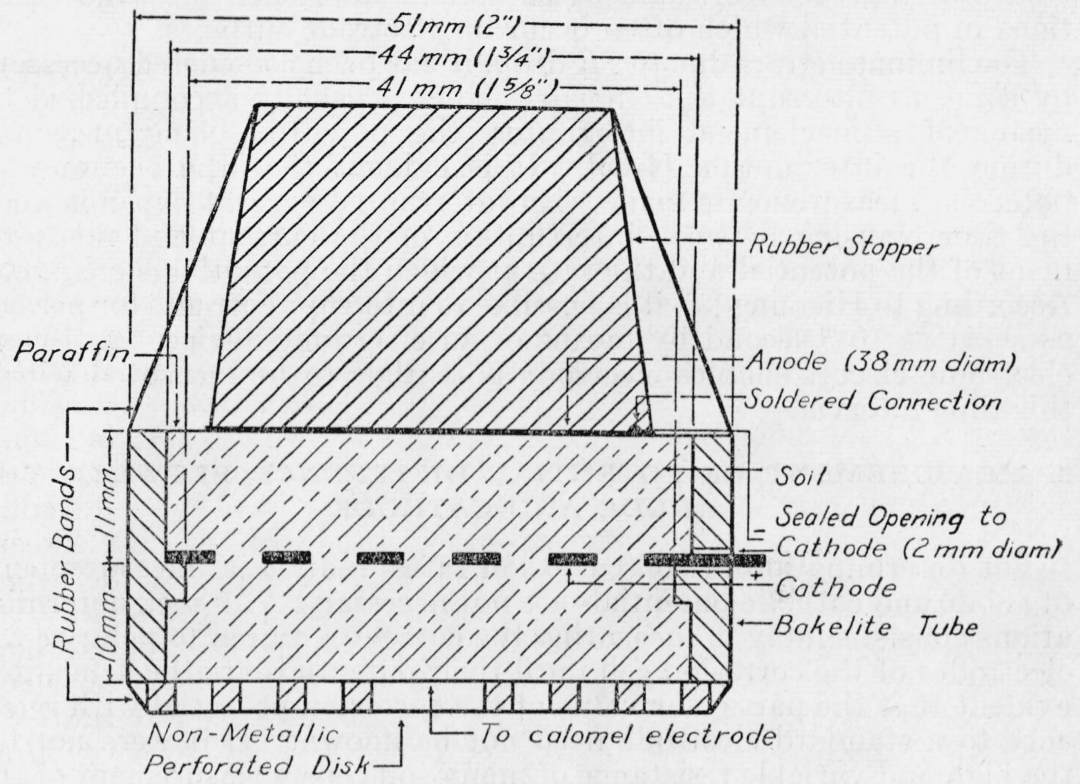

Figure 1.-Corrosion cell.

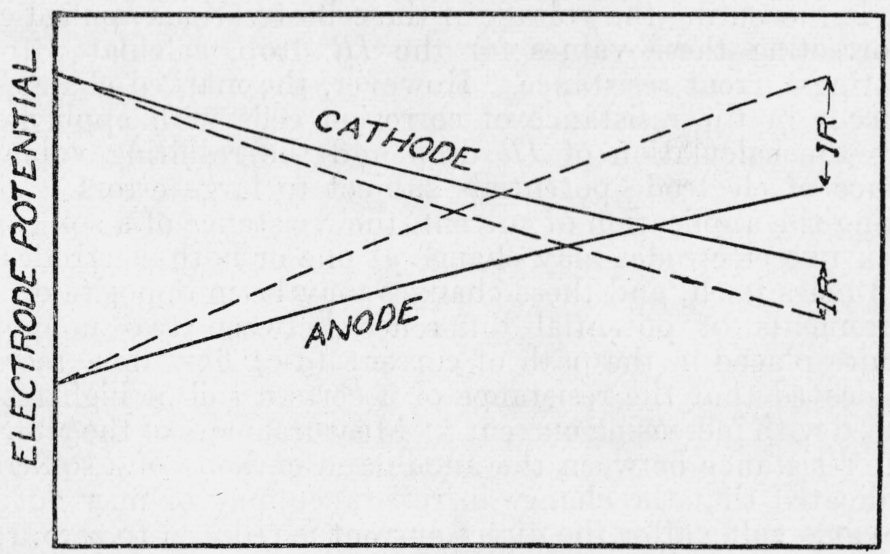

\section{CUPAENT}

FIGURE 2.-Current-density-potential curve, illustrating potential measurements in soil cells.

The broken lines illustrate measurements of potentials which include $I R$ drop. The current at the intersection of the solid lines is the current at the corrosion potential.

conducting oxide film. As film development or the deposition of corrosion products is characteristic of metals corroding under various conditions, it follows that in accurate measurements of electrode potentials in corroding environments, possible errors due to resistance films must be considered. 
Wholly apart from any error due to the resistance of films, the high resistivity of soils renders potential measurements particularly difficult. Even if the construction of the cell would permit close contact between the tip of the reference electrode and the cell electrodes, this procedure would be objectionable because of large variations in potential which often occur on eleetrode surfaces.

To eliminate errors due to $I R$ drop, it has been considered necessary by some to interrupt the current. This is usually accomplished by means of a mechanical interrupter, the potential being measured during the interruption $[4,5]$. It is evident that the accuracy of potential measurements made with interrupted current depends upon the time elapsing between interruption of the current and measurement of the potential and the rate at which the potential is changing. According to Hickling [3], it is possible to interrupt currents for periods as short as $10^{-5}$ second by means of an electronic device. A second electronic circuit enables electrode potentials to be measured within this time interval.

\section{MEASUREMENT OF POTENTIAL DIFFERENCE BETWEEN THE ANODE AND CATHODE}

For determination of soil-corrosion rates, individual measurements of anode and cathode potentials are not necessary. As such determinations consist simply in measuring the current required to polarize the electrodes of the corrosion cell until their potentials are the same, it is evident that the particular value of the corrosion potential with reference to a standard electrode need not be known. If it were not for the high and variable resistance of many soil cells, measurement of the difference of electrode potentials, as previously defined, would consist simply in measuring the voltage of the cell at various applied currents and correcting these values for the $I R$ drop, calculated from the alternating-current resistance. However, the marked changes which may occur in the resistance of corrosion cells with applied current renders the calculation of $I R$ drop and the resulting value of the difference of electrode potentials subject to large errors.

During the application of current, the resistance of a soil contained between two electrodes may change at one or both electrodes and in the soil mass itself, and these changes may be in opposite directions. Measurements of potential difference between two nonpolarizing electrodes placed in the path of current (d-c) flow in a rectangular cell indicated that the resistance of a certain soil of high resistivity decreased with increasing current. ${ }^{2}$ Measurements of the alternatingcurrent resistance between the anode and cathode of a soil-corrosion cell indicated that the change in resistance may or may not resume its previous value after the direct current is reduced to zero.

From the considerations which have been advanced in this section, it follows that methods involving the use of continuous current are

\footnotetext{
2 Decrease in resistance within the soil can be accounted for by assuming that some of the water in a moist soil is contained in discontinuous pores. As the potential difference across the cell is increased, the water is forced by endosmose into capillaries which, by forming continuous channels, increase the number of conducting paths and hence the conductance of the soil. A simultaneous increase in resistance between the anode and the soil would result from forcing the water away from the electrode under the influence of the endosmotic pressure and clogging of the soil pores with corrosion products. Changes in resistance identical in character with those which have been described have been reported by Evershed [6] in a study of insulation resistance. However, the resistances measured and the voltages applied by Evershed were much greater than those measured in the soil cells.

Aside from endosmotic effects, a probable cause of increased resistance at the anode is the deposition of corrosion products on the metal surface.
} 
open to serious objection for the measurement of electrode potentials and polarization in soil cells. Methods involving the interruption of the current would be satisfactory only to the extent that the period of interruption is sufficiently short to prevent error due to depolarization. Because of the very short period of interruption produced by the electronic method of Hickling, this method was selected for investigation.

\section{MEASUREMENT OF POTENTIALS BY THE HICKLING METHOD}

\section{DESCRIPTION OF THE METHOD}

The Hickling method for measuring the potential of polarized electrodes utilizes an electronic interrupter and an electronic poten-

INTERRUPTER CIRCUIT

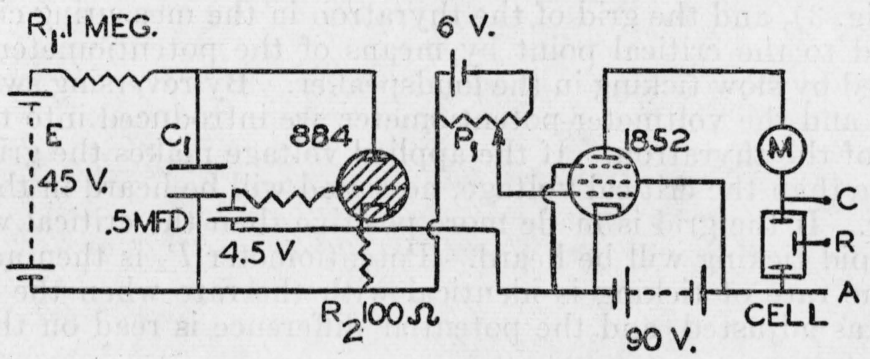

MEASURING CIRCUIT

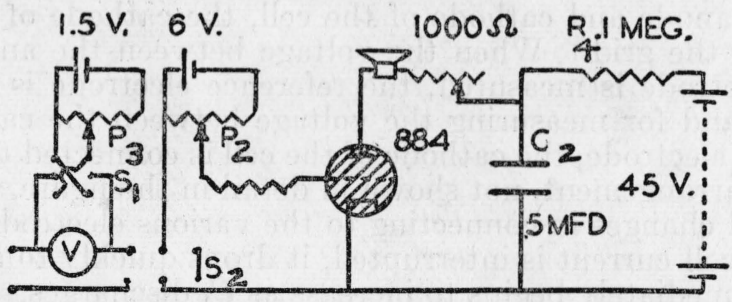

FIGURE 3.-Circuit diagram of the Hickling method.

tiometer, by means of which potentials can be measured a very short time after the current has been interrupted.

Figure 3 shows the essential parts of the interrupter and measuring circuit. Capacitor $C_{1}$ is charged through resistor $R_{1}$ until the plate of the thyratron (type 884) is at a certain potential, depending on the grid voltage. The tube then becomes conducting and capacitor $C_{1}$ discharges through the tube and resistor $R_{2}$ until the capacitor voltage drops to about 15 volts, when the tube becomes nonconducting, and the process is repeated at a rate depending on the values of $E_{1}, R_{1}, C_{1}$, and $E_{2}$.

The cell is in the plate circuit of the pentode (type 1852). Its current may be controlled by potentiometer $P_{1}$ and the $I R$ drop across $R_{2}$. Each voltage pulse across $R_{2}$ imparts a large negative potential to the 
grid of the vacuum tube, thereby interrupting the current in the cell. Resistors should be connected in series with the grid of each thyratron to limit grid current when the tubes conduct current.

The measuring circuit is an oscillating circuit similar to the interrupter circuit and will not oscillate when the grid of the thyratron is below a certain critical potential.

In measuring electrode potentials, the electrodes are connected to the grid circuit of a thyratron, the grid having been adjusted to the critical potential. The cell is so connected that the grid of the thyratron is most negative between interruptions of the current because of $I R$ drop in the cell. When the current is interrupted, the grid potential will be above or below the critical potential by an amount equal to the potential of the electrode. Adjustment of a potentiometer in the grid circuit, so that the critical potential is restored, measures the electrode potential.

In operation, double-pole double-throw switch $S_{2}$ is closed to the right (fig. 3), and the grid of the thyratron in the measuring circuit is adjusted to the critical point by means of the potentiometer $P_{2}$, as indicated by slow ticking in the loudspeaker. By reversing switch $S_{2}$, the cell and the voltmeter-potentiometer are introduced into the grid circuit of the thyratron. If the applied voltage makes the grid more negative than the critical voltage, no sound will be heard in the loudspeaker. If the grid is made more positive than the critical voltage, very rapid ticking will be heard. Potentiometer $P_{3}$ is then adjusted until the rate of ticking is identical with the rate when the critical point was adjusted, and the potential difference is read on the voltmeter.

It is important to note that the connections of the measuring circuit to the cell are determined by the direction of $I R$ drop and not by the polarity of the electrodes. Hence in measuring the voltage between the anode and cathode of the cell, the cathode of the cell is connected to the grid. When the voltage between the anode and a reference electrode is measured, the reference electrode is connected to the grid, and for measuring the voltage between the cathode and the reference electrode, the cathode of the cell is connected to the grid. A switching arrangement, not shown in detail in the figure, is used for making rapid changes in connecting to the various electrodes.

When the cell current is interrupted, it drops quickly to a very low value and immediately begins to increase as $C_{1}$ discharges. The time required for the current to decrease to a minimum and then increase until the $I R$ drop is more than 0.01 volt, the approximate limit of accuracy of the measurement, may be designated as the "effective" period of interruption. This interval corresponds to the maximum time during which the electrode depolarizes before its potential is measured.

Hickling's measurements were made with high current densities in cells of very low resistance, a triode being used as the vacuum tube. In order to make the effective period of interruption independent of the polarizing current, the latter was controlled by adjusting the filament current. For measuring potentials in soil cells in which the resistance is high and the current low, the use of a sharp cutoff pentode permitted control of the plate current in the usual way, that is, by regulation of the grid voltage. By eliminating lag in the adjustment of the current in this manner, potential measurements 
could be made immediately after the current was changed, which is usually desirable in measurements with soil cells. With variation of current and resistance over the extreme range used in corrosion studies, the effective time of interruption was found to be reasonably constant. However, the chief advantage of the pentode over the triode was the greatly improved accuracy of measurement obtained with the former tube. Pentodes of the types $6 J 7$ and 1852 have a very sharp cutoff and provided sufficient plate current for potential measurements in the soil cells.

Calculation of the effective period of interruption from the parameters of the circuit indicated that this time was about $3 \times 10^{-5}$ second. By the more direct method described below, the value $8 \times 10^{-5}$ was obtained with $R_{2}$ equal to $75 \mathrm{ohms}$. As the value of $3 \times 10^{-5}$ applies. to measurements made under static conditions, which are different from the transient conditions of operation, it is likely that the value of $8 \times 10^{-5}$ obtained by the second method is more nearly correct.

TABLE 1.-Accuracy of the Hickling method for various values of current and resistance

[Resistance in interrupter circuit $=75 \mathrm{ohms}$ ]

\begin{tabular}{|c|c|c|c|}
\hline $\begin{array}{c}\text { Resistance in } \\
\text { test circuit }\end{array}$ & Current & $I R$ & $\begin{array}{l}\text { Voltage with } \\
\text { eurrentinter } \\
\text { rupted }\end{array}$ \\
\hline $\begin{array}{r}\text { Ohms } \\
100 \\
100 \\
100 \\
100 \\
100 \\
100 \\
100\end{array}$ & $\begin{array}{r}m a \\
1.0 \\
2.0 \\
3.0 \\
5.0 \\
8.0 \\
9.0 \\
10.0\end{array}$ & $\begin{array}{c}v \\
0.1 \\
.2 \\
.3 \\
.5 \\
.8 \\
.9 \\
1.0\end{array}$ & $\begin{array}{r}v \\
+0.01 \\
+.01 \\
.00 \\
.00 \\
.00 \\
-.01 \\
-.01\end{array}$ \\
\hline $\begin{array}{l}2,000 \\
2,000 \\
2,000 \\
2,000 \\
2,000 \\
2,000\end{array}$ & $\begin{array}{l}0.5 \\
1.0 \\
2.0 \\
4.0 \\
6.0 \\
8.0\end{array}$ & $\begin{array}{r}1 \\
2 \\
4 \\
8 \\
12 \\
16\end{array}$ & $\begin{array}{l}.00 \\
.00 \\
.00 \\
.00 \\
.00 \\
.00\end{array}$ \\
\hline $\begin{array}{l}4,000 \\
4,000 \\
4,000 \\
4,000 \\
4,000 \\
4,000 \\
4,000 \\
4,000\end{array}$ & $\begin{array}{l}0.5 \\
1.0 \\
2.0 \\
4.0 \\
5.0 \\
6.0 \\
7.0 \\
7.5\end{array}$ & $\begin{array}{r}2 \\
4 \\
8 \\
16 \\
20 \\
24 \\
28 \\
30\end{array}$ & $\begin{array}{r}-.01 \\
-.01 \\
.00 \\
.00 \\
+.01 \\
+.01 \\
+.01 \\
+.02\end{array}$ \\
\hline $\begin{array}{l}6,000 \\
6,000 \\
6,000 \\
6,000 \\
6,000 \\
6,000 \\
6,000 \\
6,000\end{array}$ & $\begin{array}{l}0.5 \\
1.0 \\
2.0 \\
3.0 \\
4.0 \\
5.0 \\
6.0 \\
6.2\end{array}$ & $\begin{array}{c}3 \\
6 \\
12 \\
18 \\
24 \\
30 \\
36 \\
37.2\end{array}$ & $\begin{array}{r}-.02 \\
-.01 \\
-.01 \\
.00 \\
+.01 \\
+.02 \\
+.02 \\
+.03\end{array}$ \\
\hline $\begin{array}{l}10,000 \\
10,000 \\
10,000 \\
10,000 \\
10,000 \\
10,000\end{array}$ & $\begin{array}{l}0.1 \\
.5 \\
1.0 \\
2.0 \\
3.0 \\
4.0\end{array}$ & $\begin{array}{r}1 \\
5 \\
10 \\
20 \\
30 \\
40\end{array}$ & $\begin{array}{r}+.02 \\
+.02 \\
+.02 \\
+.02 \\
+.03 \\
+.10\end{array}$ \\
\hline
\end{tabular}

The effective period of interruption was measured as follows. A capacitor and a resistor in parallel were connected in the circuit in place of the cell. The potential of the capacitor was measured with continuous current and with interrupted current. The first measurement gave the initial potential of the capacitor; the second, the 
potential to which it discharged. The effective period of interruption was then calculated from the known values of the resistance and capacitance.

The periods of interruption given above are, of course, not comparable with those obtained by Hickling for the same value of $R_{2}$, since the period of interruption depends on factors other than $R_{2}$.

To determine the extent to which measurements of electrode potentials had been made independent of both current and resistance, various resistors were used successively in place of the cell, and the potential difference across the resistance was measured as the current was varied. The shortest time interval was used. As there is practically no IR drop when the plate current is interrupted, the potential difference should of course be zero.

The data of table 1 show that within the range of current commonly applied to soil-corrosion cells and within the normal range of resistance of these cells, the combined effect of current and resistance on the accuracy of potential measurements is not over 0.01 volt. The larger errors shown in the table correspond to higher $I R$ drops than are met with in practice. It is to be noted that accurate measurements were made with $I R$ drops as much as 20 volts, except with the highest resistance of 10,000 ohms.

\section{VALUES OF POTENTIAL FOR DIFFERENT PERIODS OF INTER- RUPTION}

TABLE 2.-Values of potential difference between the anode and cathode, and singleelectrode potentials for different periods of interruption

\begin{tabular}{|c|c|c|c|c|c|c|c|c|}
\hline \multicolumn{2}{|r|}{ Soil } & \multirow{2}{*}{$\begin{array}{l}\text { Current } \\
\text { density }\end{array}$} & \multicolumn{6}{|c|}{ Resistance in interrupter circuit-ohms } \\
\hline No.1 & Type & & 100 & 200 & 400 & 600 & 1,000 & 2,000 \\
\hline \multirow{3}{*}{$\begin{array}{r}55 \\
113 \\
17 \\
17 \\
20 \\
23 \\
23 \\
28 \\
28 \\
64 \\
43 \\
45 \\
45\end{array}$} & \multirow[b]{2}{*}{$\begin{array}{l}\text { Hagerstown loam } \\
\text { Imperial clay } \\
\text { Keyport loam } \\
\text { Maho do } \\
\text { Merced sing silt loam } \\
\text { Montezuma clay adobe } \\
\begin{array}{l}\text { Salinas elay adobe } \\
\text { Tidal marsh } \\
\text { Unidentified alkali soil }\end{array}\end{array}$} & \multirow[b]{2}{*}{$\begin{array}{c}m a / d m{ }^{2} \\
1.8 \\
35.1 \\
13.2 \\
26.3 \\
13.2 \\
8.8 \\
87.7 \\
4.4 \\
35.1 \\
8.8 \\
35.1 \\
8.8 \\
35.1\end{array}$} & \multicolumn{6}{|c|}{ Potential difference between anode and cathode } \\
\hline & & & $\begin{array}{r}v \\
+0.28 \\
+.40 \\
+.16 \\
+.38 \\
+.36 \\
+.06 \\
+.38 \\
+.12 \\
+.12 \\
+.22 \\
+.37 \\
+.01 \\
+.12\end{array}$ & $\begin{array}{l}\quad v \\
+0.25 \\
+.40 \\
+.14 \\
+.35 \\
+.34 \\
+.06 \\
+.37 \\
+.13 \\
+.11 \\
+.22 \\
+.36 \\
+.01\end{array}$ & \begin{tabular}{r}
$v$ \\
+0.23 \\
+.40 \\
+.11 \\
+.31 \\
+.32 \\
\hdashline .07 \\
+.35 \\
+.13 \\
+.10 \\
+.22 \\
+.36 \\
+.02 \\
+.11
\end{tabular} & \begin{tabular}{r}
$v$ \\
+0.22 \\
+.39 \\
+.10 \\
+.29 \\
+.31 \\
-.07 \\
+.34 \\
+.14 \\
+.10 \\
\hdashline .36 \\
+.02 \\
+.10
\end{tabular} & $\begin{array}{r}v \\
+0.20 \\
+.39 \\
+.09 \\
+.26 \\
+.30 \\
+.07 \\
+.34 \\
.14 \\
+.09 \\
+.22 \\
+.36 \\
+.02 \\
+.10\end{array}$ & $\begin{array}{r}v \\
+0.18 \\
+.39 \\
+.07 \\
+.24 \\
+.28 \\
-.08 \\
+.32 \\
+.14 \\
+.09 \\
-.23 \\
+.36 \\
+.03 \\
+.08\end{array}$ \\
\hline & & & & & atnod & tenti & & \\
\hline \multirow[t]{2}{*}{20} & Mahoning silt loam & 13.2 & -0.82 & -0.81 & -0.79 & -0.79 & -0.77 & -0.77 \\
\hline & & & \multicolumn{6}{|c|}{ Anode potentials 2} \\
\hline 17 & Keyport loam.... & 26.3 & -0.38 & -0.35 & -0.31 & -0.29 & -0.26 & -0.24 \\
\hline
\end{tabular}

1 Numbers refer to test sites of National Bureau of Standards soil-corrosion investigation.

2 Potentials measured with respect to saturated calomel electrode.

Since the period of interruption of the current is related to the resistance $R_{2}$ in the interrupter circuit, varying this resistance provides a convenient means for varying the period of interruption, and hence 
for studying the rate of depolarization of the soil cells. In table 2 have been tabulated the measured voltages of soil cells for different periods of interruption corresponding to the value of resistance shown in the table. The soils selected for study exhibit a wide range of chemical and physical properties. It will be recalled from figure 2 that negative values indicate that the open-circuit voltage of the cell is greater than the voltage produced by polarization.

The rates of depolarization of the soil cells are seen to be subject to wide variation. In a few soils the maximum difierence in voltage between the shortest and longest period of interruption was little more than 0.01 volt. In other soils this difference was 0.1 volt or more. It is of some interest to note from the measurements of separate electrode potentials that rapid depolarization may occur at the anode as well as the cathode.

\section{MEASUREMENT OF POTENTIALS BY MEANS OF ALTER- NATING CURRENT WITH ELIMINATION OF IR DROP}

An alternate method for measuring electrode potentials made use of both alternating and direct current. This method is based on the fact that if, for a given resistance, the peak value of $I R$ drop with alternating current is equal to the $I R$ drop with direct current, the two $I R$ drops will be equal for any other resistance, as for example, the resistance of a cell whose voltage is to be measured. If the peak value of alternating current introduced in a circuit in which direct current is flowing is made equal to the direct current, it is evident that for an instant in each cycle the cell current and hence the $I R$ drop in the cell will be zero. If a vacuum-tube voltmeter for measuring peak voltages or other suitable instrument is connected across the cell, electrode potentials at this instant can then be measured. In the present study, the electronic potentiometer described in the previous section was used for measuring potentials by this method. The circuit diagram is shown in figure 4.

The direct current in the cell circuit is adjusted to the desired values, as indicated by a direct-current milliammeter. With the thyratron in the measuring circuit (fig. 3) adjusted to its critical point, as indicated by the slow regular ticking in the loudspeaker, the measuring circuit is connected across resistor $R_{1}$ (fig. 4 ), $P_{3}$ being set at zero. As the grid of the thyratron is made more negative by the $I R$ drop across the resistance, the ticking ceases. The alternating current is then adjusted until the critical point is restored. At this point the IR drop for the peak alternating and direct currents is the same, not only for the resistor but also for the cell regardless of its resistance. The measuring circuit is now connected across the cell and the critical point restored by changing the grid potential of the thyratron. The reading of the voltmeter at the critical point measures the potential difference between the anode and cathode of the cell or, if a reference electrode is used, the potential of each electrode is measured.

The test resistance in the circuit should have a value at least equal to the resistance of the cell. Otherwise, any error in adjustment with the voltmeter connected across the resistor would be increased when the voltmeter is connected across the cell. It is also essential that the voltage of the alternating current be constant over the interval during which the voltage is measured. The alternating current is adjusted 
by a potentiometer in the primary circuit of the transformer so as not to change the resistance, and therefore the direct current, in the cell circuit. As with the interrupter method, the measuring circuit is so connected to $R_{1}$ (fig. 3 ) and the cell that the $I R$ drop in the current circuit makes the grid of the thyratron more negative.

The frequency of the alternating current necessarily has an important bearing on the accuracy of the potential measurements, particularly if the rate of depolarization is rapid. As the direct current is alternately opposed and increased by the alternating current, the potential of the electrodes necessarily varies with the fluctuating current. Since the average value of the polarizing current is reached when the alternating current is zero, it follows that at that point in the cycle when the potential is measured, that is, when the IR drop is zero, the voltage of the cell is different from its average value, depending on the rate of depolarization of the cell and the frequency of the current. With 60-cycle current, which was the only frequency available with the required constant voltage, some depolarization occurred

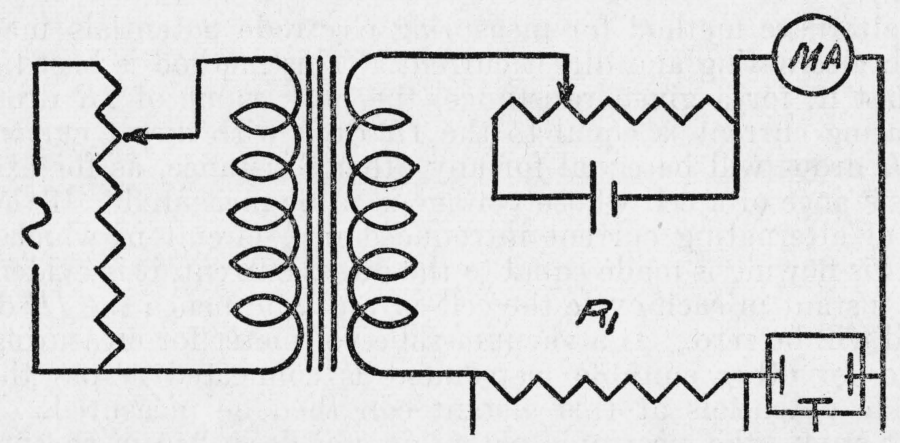

FIgURE 4.-Circuit diagram of method employing alternating current.

in the case of those cells which depolarized rapidly, as will be seen later. However, as the primary purpose of this method was to test the effect of cell resistance on the accuracy of the Hickling method, only cells which did not depolarize rapidly were used for comparison. For testing the accuracy of the Hickling method in cells which depolarized with extreme rapidity, the direct method, using continuous current, was employed. It is probable that the accuracy of the method could be improved by increasing the frequency of the alternating current.

\section{MEASUREMENT OF POTENTIAL DIFFERENCE BETWEEN THE ANODE AND CATHODE}

Measurements were made of the voltage between the anode and cathode in a group of soil-corrosion cells of low resistance. For each value of current the voltage across the cell was measured with a highresistance voltmeter. The voltage measurements were corrected for IR drop, which was calculated from the current and the alternatingcurrent resistance of the cell. Because of the tendency of the resistance of cells containing soils of high resistivity to vary with current, measurements were necessarily restricted to low-resistance cells. In the particular cells used, no change in cell resistance could be detected between the extremes of applied current. Corrections in resistance 
measurements made for capacitance in the cells were negligible, as were corrections for the accuracy of the voltmeter and ammeter and the resistance of the voltmeter.

\section{COMPARISON OF POTENTIAL MEASUREMENTS BY DIFFERENT METHODS}

Potential measurements made during interruption of current are necessarily subject to some uncertainty, even when the shortest time interval is utilized. In order to arrive at values for the instantaneous potentials of electrodes which depolarized with extreme rapidity, both Glasstone [4] and Hickling [3] found it necessary to plot potentials measured at various periods of interruption and to extrapolate to zero time. As such relations are empirical, it does not necessarily follow that the extrapolated values are always correct. For this reason it was considered especially important to compare the measurements made with the Hickling method with those obtained by an alternate method, preferably one which required the use of continuous current.

In table 3 are shown values for single electrode potentials and potential differences between the anode and cathode measured by the Hickling method. Potential differences measured by the direct method are also shown for comparison. It will be noted that the values measured by the two methods do not differ by more than 0.01 volt.

TABLE 3.-Potential measurements made by the Hickling method and the direct method

[Soil 113. Imperial clay. Cell resistance, $6.5 \mathrm{ohms}$ ]

\begin{tabular}{|c|c|c|c|c|c|}
\hline \multirow[b]{2}{*}{ Current density } & \multicolumn{4}{|c|}{ Hickling method } & \multirow{2}{*}{$\begin{array}{c}\text { Direct } \\
\text { method } \\
\text { (cor- } \\
\text { rected) } \\
\text { anode } \\
\text { to } \\
\text { cathode }\end{array}$} \\
\hline & Anode & Cathode & $\begin{array}{l}\text { Differ- } \\
\text { ence }\end{array}$ & $\begin{array}{l}\text { Anode } \\
\text { to rath- } \\
\text { ode } \\
\text { (meas- } \\
\text { ured) }\end{array}$ & \\
\hline $\begin{array}{l}\text { ma/dm } \\
0 \\
1 \\
2.5 \\
10 \\
20 \\
30 \\
40\end{array}$ & $\begin{array}{c}v \\
0.62 \\
.60 \\
.60 \\
.58 \\
.56 \\
.54 \\
.53 \\
.52\end{array}$ & $\begin{array}{l}v \\
0.58 \\
.58 \\
.58 \\
.59 \\
.62 \\
.70 \\
.78 \\
.83\end{array}$ & $\begin{aligned} v \\
-0.04 \\
-.03 \\
-.01 \\
+.01 \\
+.06 \\
+.16 \\
+.25 \\
+.31\end{aligned}$ & $\begin{aligned} & v \\
&-0.04 \\
&-.02 \\
& .00 \\
&+.02 \\
&+.05 \\
&+.15 \\
&+.25 \\
&+.31\end{aligned}$ & $\begin{array}{r}v \\
-0.02 \\
.00 \\
+.01 \\
+.05 \\
+.16 \\
+.26 \\
+.31\end{array}$ \\
\hline
\end{tabular}

Before drawing final conclusions concerning the accuracy of the Hickling method as a general method for measuring electrode potentials in soils, it is obviously necessary that comparative measurements with other methods be made on soils which show a wide range of properties. The soils selected range in reaction between $\mathrm{pH} 3.1$ and 9.4 , in resistivity between 60 and $7,000 \mathrm{ohm}-\mathrm{cm}$, and in texture from. porous loams to an extremely heavy clay.

In table 4 are given values of the potential difference between the anode and cathode obtained by the three methods which have been described. Because of the inaccuracy of the direct method when applied to cells of high resistance, measurements in such cells were not made by this method. 
It will be noted that the values given in the two columns for the Hickling method are not identical. These measurements were made at different times, between which the potentials of the electrodes had changed slightly.

TABLE 4.-Measurements of potential differences between anode and cathode bis different methods

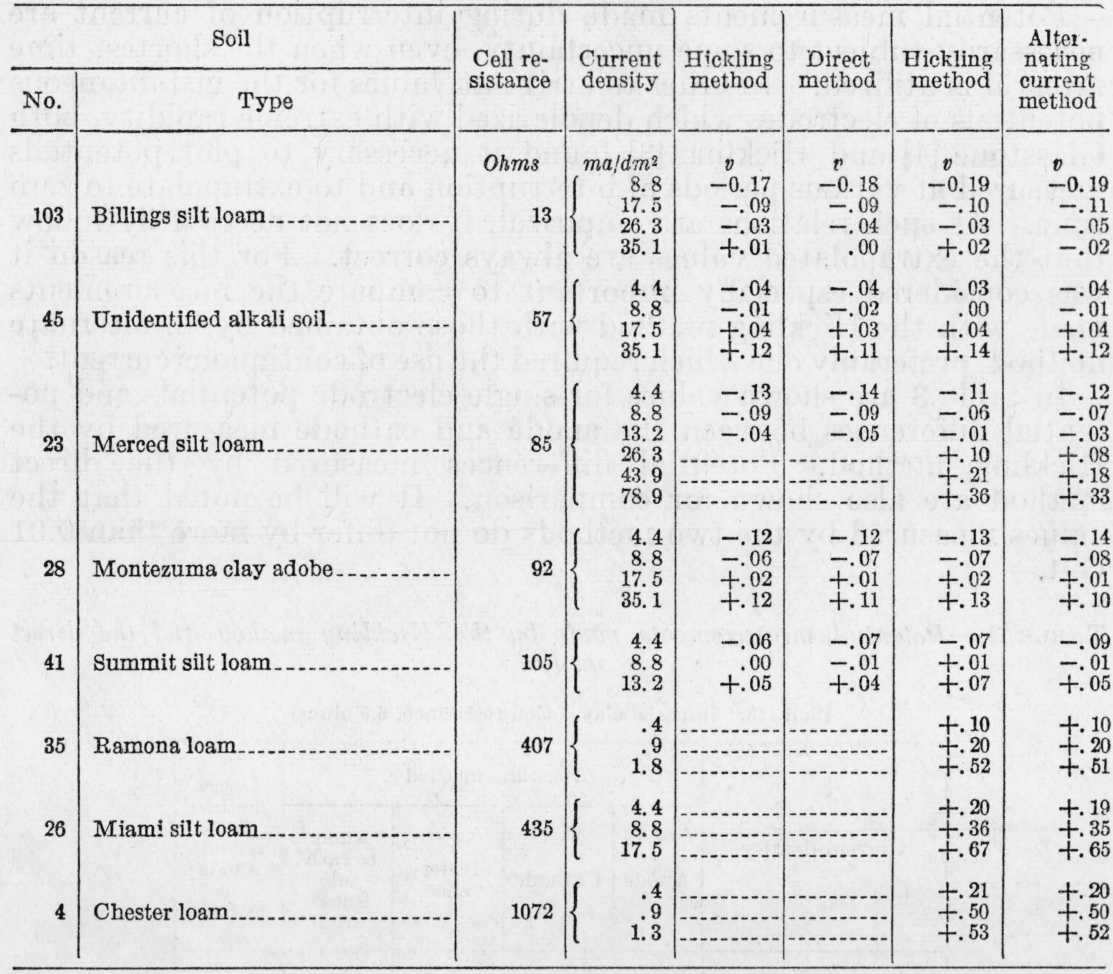

The average error between the Hickling method and the direct method is within 0.01 volt for every soil for which comparative data are given. While it cannot be stated that the true electrode potentials were measured by either the Hickling or the direct method, the consistently good agreement which was obtained indicates that the true values were at least closely approached.

The agreement between the Hickling method and the alternatingcurrent method was generally good except in those cells in which depolarization was especially rapid. As would be expected, the error between the two methods becomes greater as higher current densities are applied. The values for the Merced silt loam illustrate these tendencies. It will be noted that the differences between the two methods in this soil gradually increase with increasing current density, reaching a maximum difference of 0.03 volt at the highest current density. By referring to table 2, it is seen that the polarization voltage in this cell at about the same current density drops 0.03 volt 
when the resistance in the interrupter circuit is increased from 100 to 400 ohms.

The fact that there is disagreement between the Hickling method and the alternating-current method in certain soils was to be expected when low frequency current was used for the latter method. The significant fact is that the Hickling method is not subject to error from cell current and resistance within the range typical for highresistance cells, as shown by good agreement between this method and the alternating-current method in high-resistance cells in which rapid depolarization was not a source of error. However, the data in table 1 indicate that errors are small over a much wider range of current and resistance, even when the rate of depolarization is rapid.

Although the modifications which have been introduced into the Hickling method were for the purpose of adapting it to measurements in soils, it would seem that the method as modified would be well adapted to high-resistance solutions, such as natural waters, particularly in connection with potential measurements of metals which naturally develop high-resistance films.

\section{REFERENCES}

[1] I. A. Denison, J. Research NBS 17, 363 (1936)RP918.

[2] I. A. Denison and R. B. Darnielle, Trans. Electrochem. Soc. 76, 199 (1939).

[3] A. Hickling, Trans. Faraday Soc. 33, 1540 (1937).

4 S. Glasstone, J. Chem. Soc. 123, 2926 (1923); 125, 250 (1924).

5] E. Newbery, Trans. Electrochem. Soc. 58, 187 (1930).

6] S. Evershed, J. Inst. Elec. Engrs. (London) 52, 51 (1914).

Washington, June 17, 1940. 